Удк 339.138:659.118

DOI https://doi.org/10.32851/2708-0366/2020.4.10

\begin{abstract}
Капінус Л.В.
кандидат економічних наук, доцент, доцент кафедри маркетингу, Начіональний університет харчових технологій ORCID: https://orcid.org/0000-0002-6135-7885
\end{abstract}

Розумей С.Б. кандидат економічних наук, Національний університет харчових технологій ORCID: https://orcid.org/0000-0002-0044-7043

Наконечна Д.С. магістрантка,

Національний університет харчових технологій

Kapinus Larysa, Rozumei Svitlana, Nakonechna Daria National University of Food Technologies

\title{
МАРКЕТИНГОВА ПОВЕДІНКА ПІДПРИЄМСТВ НА ОНЛАЙН-РИНКУ
}

\section{MARKETING BEHAVIOR OF ENTERPRISES ON THE ONLINE-MARKET}

У статті визначено основні тенденції розвитку онлайн-ринку електронної комериії, який почав стрімко зростати через економічну кризу, що викликана пандемією Covid-19. Здійснено порівняльну характеристику онлайн-ринку В2B- та B2C-секторів за визначеними критеріями, такими як розмір онлайн-ринку, вартість продукиї та послуг, взаємовідносини з клієнтами, програма лояльності, служба підтримки та консультачія, маркетингові иілі, контент-стратегія. Розроблено моделі маркетингової поведінки підприємств на онлайн-ринку В2В та В2С, у яких підприємство розглядається як відкрита система, що має маркетингові иілі та стратегічну місію. Запропоновано типи маркетингової поведінки підприємства на онлайн-ринку, такі як пасивна та активна, уточнено зміст цих понять. Задля досягнення активної поведінки підприємства на онлайн-ринку варто використовувати ефективні інструменти інтернет-маркетингу для B2C- та В2В-секторів.

Ключові слова: онлайн-маркетинг, поведінка, онлайн-ринок, В2B, B2C, споживачі.

В статье определены основные тенденции развития онлайн-рынка электронной коммерции, который начал стремительно расти из-за экономического кризиса, который вызван пандемией Covid-19. Осуществлена сравнительная характеристика онлайн-рынков B2B- и В2C-секторов по определенным критериям, таким как размер онлайн-рынка, стоимость продукиии и услуг, взаимоотношения с клиентами, программа лояльности, служба поддержки и консультачия, маркетинговые иели, контент-стратегия. Разработаны модели маркетингового поведения предприятий на онлайн-рынке B2B и В2C, в которых предприятие рассматривается как открытая система, имеющая маркетинговые иели и стратегическую миссию. Предложены типы маркетингового поведения предприятия на онлайн-рынке, такие как пассивное и активное, уточнено содержание этих понятий. С иелью достижения активного поведения предприятия на онлайн-рынке стоит использовать эффективные инструменты интернет-маркетинга для B2C-и В2B-секторов.

Ключевые слова: онлайн-маркетинг, поведение, онлайн-рынок, В2В, В2С, потребители.

In the modern economy there are accelerated processes of transformation of business models that support the trends of economic globalization. With new challenges, new forms of marketing are emerging, new markets are opening up, new channels of communication with consumers are being used, and online marketing tools are being used to promote goods. Such changes necessitate the modeling of marketing behavior of enterprises that have entered the online market to improve the marketing activities of the enterprise and achieve its strategic goals. The study identified the 
main trends in the development of the online e-commerce market, which began to grow rapidly due to the economic crisis caused by the Covid-19 pandemic. The comparative characteristics of the online market of $B 2 B$ and B2C sectors are carried out according to certain criteria, such as the size of the online market, the cost of products and services, customer relations, loyalty program, support and consultation, marketing goals, content strategy. A model of marketing behavior of the enterprise in the B2B online market is developed, in which the enterprise is considered as an open system, it has marketing goals in the online market, includes the process of making decisions about online procurement and the company's reaction to online purchasing. A model of marketing behavior of the enterprise in the B2C online market is also proposed, in which the enterprise is also considered as an open system, has strategic marketing goals and mission in the online market, includes the online sales decision-making process and responds to the online marketing process. Marketing behavior of enterprises in the period of adaptation to new conditions should be based on the results of monitoring trends in the external environment of the enterprise, as well as take into account changes in the main marketing indicators of the enterprise itself. The types of marketing behavior of the enterprise in the online market, such as passive and active, are offered, the content of these concepts is specified. In order to achieve active business behavior in the online market, you should use effective Internet marketing tools for B2C and B2B markets, such as content marketing, search engine optimization, paid online advertising, email, social networks with the ability to advertise and target, marketing influence. A further perspective of the study may be the consideration and selection of criteria on the basis of which it is possible to develop a methodology for determining the marketing behavior of the enterprise in the online market.

Key words: online marketing, behavior, online market, B2B, B2C, consumers.

Постановка проблеми. В сучасній економіці відбуваються прискорені процеси трансформації бізнес-моделей, що підтримують тенденції економічного глобалізаційного розвитку. У зв'язку з новими викликами виникають нові форми ведення маркетингової діяльності, відкриваються нові ринки, використовуються нові канали зв'язку зі споживачами, застосовуються маркетингові онлайн-інструменти просування товару. Такі зміни обумовлюють необхідність моделювання маркетингової поведінки підприємств, які вийшли на онлайн-ринок, для покращення маркетингової діяльності підприємства та досягнення його стратегічних цілей.

3 огляду на актуальність теми вичерпних досліджень усіх аспектів цього напрямку маркетингової науки немає, тому питання потребує додаткового вивчення, зокрема формування теоретичного базису для моделювання маркетингової поведінки підприємств на онлайн-ринку для досягнення цілей підприємства в сучасних нестабільних умовах.

Аналіз останніх досліджень і публікацій. Вирішенню проблем формування та моделювання поведінки підприємств приділялась увага багатьох учених, таких як Г. Капленко [13], Н. Карачина [12], I. Козлова [13], В. Цапенко [16].

Вважається, що саме економічна поведінка є провідним поняттям для подальшого вивчення поведінкових моделей підприємства, зокрема маркетингової поведінки підприємства на онлайн-ринку.

Формулювання цілей статті. Для розкриття теми дослідження необхідно вивчити стан розвитку електронної комерції та розробити маркетингові поведінкові моделі підприємств на онлайн-ринку в секторах В2В та В2С.

Виклад основного матеріалу. Сучасні підприємства задля успішного розвитку реагують на виклики сьогодення, зокрема на економічні проблеми, що викликані пандемією Covid-19. Нова економіка бурхливо супроводжується розвитком комунікаційних та інформаційних технологій, які активно впливають на зміну організаційних механізмів управління маркетинговою діяльністю підприємств. 3 появою Інтернету змінюються традиційні економічні моделі ведення бізнесу, а саме процеси трансформації та глобалізації невпинно продовжують входити у виробничо-господарську діяльність підприємств та змінювати їхні поведінкові моделі.

Тоді як деякі підприємства залишаться закритими або їхня діяльність матиме кризовий характер у зв'язку з викликами, пов'язаними з пандемією Covid-19, інші 
зможуть побачити величезне зростання. Основними причинами розвитку є швидка адаптація підприємств до змін, переорієнтація на нові канали продажу та інструменти комунікації зі споживачами, використання електронної комерції.

3 огляду на світові виклики ринок електронної комерції у світі значно зріс за останні роки (рис. 1). Кількість інтернет-користувачів постійно збільшується, покращується культура використання мережі, зростає кількість онлайн-майданчиків для продажу товарів. Спираючись на статистику досліджень компанії "EVO” (Prom.ua, Shafa.ua, Bigl.ua, Crafta.ua, Izi.ua), німецького онлайн-порталу статистики "Statista" i сервісу "OLX”, зазначаємо, що ринок електронної комерції в Україні у 2019 році склав близько 97,4 млрд. грн. Із січня по листопад 2019 року фізичних товарів i послуг було продано на 76 млрд. грн. Це на 17\% більше, ніж за аналогічний період у 2018 році. Згідно з прогнозами, у 2020 році ринок фізичних товарів і послуг зросте ще більше, склавши 87,2 млрд. грн. Цікаво, що в минулому році суттєво збільшилися доходи від онлайн-реклами, інтернет-просування, оплати онлайн і доставки. За даними Всеукраїнської рекламної коаліції, виручка від реклами в соціальних мережах, на онлайн-ресурсах і маркетплейсах склала близько 16 млрд. грн. Це на 37\% більше, ніж у 2018 році. На доставці було зароблено не менше 3,5 млрд. грн., а на онлайн-оплаті - 1,9 млрд. грн. [8; 15].

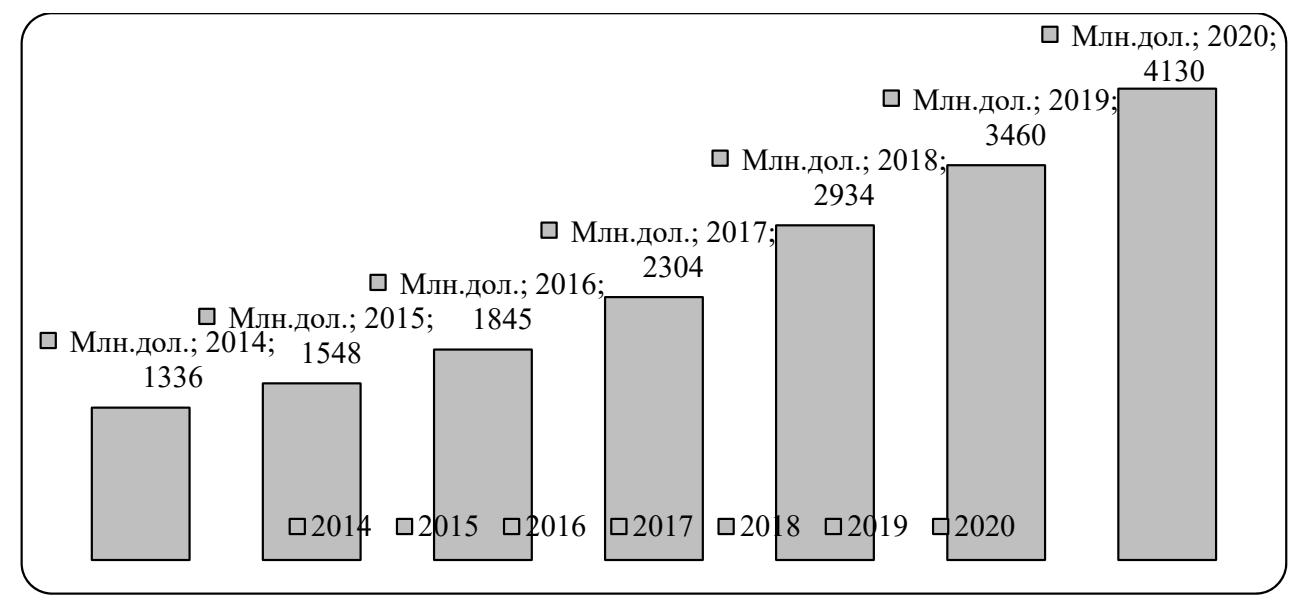

Рис. 1. Тендениії розвитку світового ринку електронної комериії, млн. дол.

Джерело: [8] з урахуванням впливу пандемії Covid-19

В навколишньому середовищі підприємств як у секторі В2B, так і в секторі В2C постійно відбуваються ті чи інші події, які вимагають швидких та чітких реакції. Рівень успіху залежить від якості пристосування до ситуації в навколишньому середовищі. Кожне підприємство визначає свої цілі та місію, за допомогою своїх поведінкових реакцій на економічні виклики формує маркетингову поведінку на онлайн-ринку. Авторами зроблено порівняльну характеристику онлайн-ринку в секторах В2В та В2С за певними критеріями (табл. 1).

На думку авторів, маркетингова поведінка підприємств в період адаптації до нових умов має базуватись на результатах моніторингу тенденцій зовнішнього середовища підприємства, а також враховувати зміни основних маркетингових показників діяльності самого підприємства. Крім того, мають бути моделі маркетингової поведінки підприємств для кожного сектору підприємницької діяльності (рис. 2, рис. 3). 
Порівняльна характеристика онлайн-ринку на В2С та В2В

\begin{tabular}{|c|c|c|}
\hline \multirow[t]{2}{*}{ Критерій } & \multicolumn{2}{|c|}{ Сектор підприємницької діяльності } \\
\hline & B2C & B2B \\
\hline Розмір ринку & $\begin{array}{l}\text { Для В2С-моделі характерний великий розмір } \\
\text { ринку та цільової аудиторії. Товари та послу- } \\
\text { ги користуються широким попитом. }\end{array}$ & $\begin{array}{l}\text { На відміну від В2С-моделі, } \\
\text { В2В вирішує специфічні, ін- } \\
\text { дивідуальні завдання бізнесу. }\end{array}$ \\
\hline $\begin{array}{l}\text { Вартість } \\
\text { продукцї і } \\
\text { послуг }\end{array}$ & $\begin{array}{l}\text { У В2С-компанії може бути більше клієнтів, } \\
\text { ніж В2В. При цьому через те, що вартість по- } \\
\text { слуг або товару у В2В вище, один В2В-клієнт } \\
\text { може окупити всі маркетингові вкладення, } \\
\text { витрачені на його залучення. }\end{array}$ & $\begin{array}{l}\text { Ціни в В2В-сегменті значно } \\
\text { вище. Клієнт - це інший біз- } \\
\text { нес } 3 \text { рівнем доходу вище, ніж } \\
\text { у окремо взятої людини. Од- } \\
\text { нак і тут є обмеження: не кож- } \\
\text { на компанія готова витрачати } \\
\text { гроші на джерело непрямого } \\
\text { доходу. }\end{array}$ \\
\hline $\begin{array}{l}\text { Взаємо- } \\
\text { відносини } 3 \\
\text { клієнтом }\end{array}$ & $\begin{array}{l}\text { Близько 80\% прибутку бізнесу приносить } \\
20 \% \text { постійних клієнтів. Однак В2С-бізнес } \\
\text { може жити з разових продажів. }\end{array}$ & $\begin{array}{l}\text { Для В2В-моделі постійні клі- } \\
\text { єнти - це must have. }\end{array}$ \\
\hline $\begin{array}{l}\text { Програма } \\
\text { лояльності }\end{array}$ & $\begin{array}{l}\text { Правильно складена й пророблена програ- } \\
\text { ма лояльності збільшує продажі і прибуток } \\
\text { бізнесу як для В2С-, так і для В2В-моделей } \\
\text { бізнесу. }\end{array}$ & \\
\hline $\begin{array}{l}\text { Служба } \\
\text { підтримки та } \\
\text { консультація }\end{array}$ & $\begin{array}{l}\text { І в В2В-, і в В2С-моделі у клієнтів виникають } \\
\text { питання вибору товару або послуги, викори- } \\
\text { стання продуктів, умов співпраці. Вся необ- } \\
\text { хідна інформація має бути в розділі гарантій, } \\
\text { доставки та оплати на спеціальних сторінках } \\
\text { сайту. Наявність такої інформацї̈- це один з } \\
\text { чинників ранжування для пошукових систем. }\end{array}$ & \\
\hline Цілі & $\begin{array}{l}\text { Метою В2С є продаж товару або послуги } \\
\text { швидко, поки споживач не пішов шукати їі } \\
\text { назад через пошукову систему або сайт кон- } \\
\text { курентів. }\end{array}$ & $\begin{array}{l}\text { Метою В2В є детальне роз- } \\
\text { криття особливостей співп- } \\
\text { раці, товару або послуги, } \\
\text { демонстрація потенційному } \\
\text { бізнес-клієнту особливостей } \\
\text { роботи, переваг і репутації } \\
\text { бізнесу на ринку. }\end{array}$ \\
\hline $\begin{array}{l}\text { Контент- } \\
\text { стратегія }\end{array}$ & $\begin{array}{l}\text { Для В2С це стратегія залучення нових корис- } \\
\text { тувачів, підвищення впізнавання бренду. }\end{array}$ & $\begin{array}{l}\text { Для В2В це стратегія підви- } \\
\text { щення експертності та види- } \\
\text { мості лідерства на ринку. }\end{array}$ \\
\hline
\end{tabular}

Джерело: узагальнено авторами на основі [4; 9; 11; 14; 15$]$

\begin{tabular}{|c|c|c|c|}
\hline \multirow[b]{2}{*}{$\begin{array}{c}\text { Маркетингові } \\
\text { чинники } \\
\text { зовнішнього } \\
\text { середовища } \\
\text { підприємства }\end{array}$} & \multicolumn{2}{|c|}{$\begin{array}{l}\text { Підприємство як відкрита система } \\
\text { (має маркетингові цілі на онлайн-ринку) }\end{array}$} & $\begin{array}{c}\text { Реакція підприємства } \\
\text { на онлайн-закупівлі }\end{array}$ \\
\hline & $\begin{array}{l}\text { Маркетингові } \\
\text { чинники } \\
\text { внутрішнього } \\
\text { середовища } \\
\text { підприємства }\end{array}$ & $\begin{array}{c}\text { Процес } \\
\text { прийняття } \\
\text { рішень про } \\
\text { онлайн-закупівлі }\end{array}$ & $\begin{array}{l}\text { - вибір сировини, } \\
\text { матеріалів, послуг; } \\
\text { - вибір ціни; } \\
\text { - вибір } \\
\text { постачальників; }\end{array}$ \\
\hline & & & покупки \\
\hline
\end{tabular}

Рис. 2. Модель маркетингової поведінки підприємства на онлайн-ринку В2B 


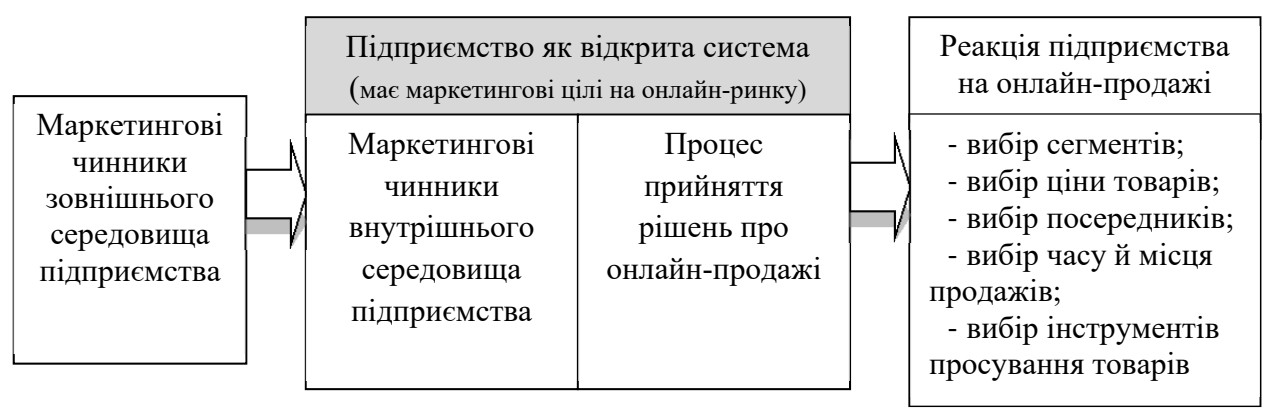

Рис. 3. Модель маркетингової поведінки підприємства на онлайн-ринку В2С Джерело: розроблено авторами

Як бачимо, моделі різняться між собою процесом прийняття рішення про онлайн-діяльність, різною є реакція підприємства на поведінкові дії на онлайн-ринку, крім того, аналіз поведінки онлайн-споживачів буде здійснюватися за різними підходами, критеріями та методиками. Моделі враховують умови формування чинників впливу на маркетингову поведінку підприємств на онлайн-ринку.

Сучасна маркетингова наука вважає, що всі економічні суб'єкти прагнуть до раціональної комбінації маркетингових чинників та узгодженості дій і економічних інтересів учасників онлайн-ринку. Важливо враховувати основні мотиви маркетингової діяльності, на основі чого формується маркетингова поведінка підприємства. Автори виділяють два поведінкових типи, а саме активна маркетингова поведінка підприємства на онлайн-ринку та пасивна маркетингова поведінка підприємства на онлайнринку. Авторське трактування понять зображено на рис. 4.

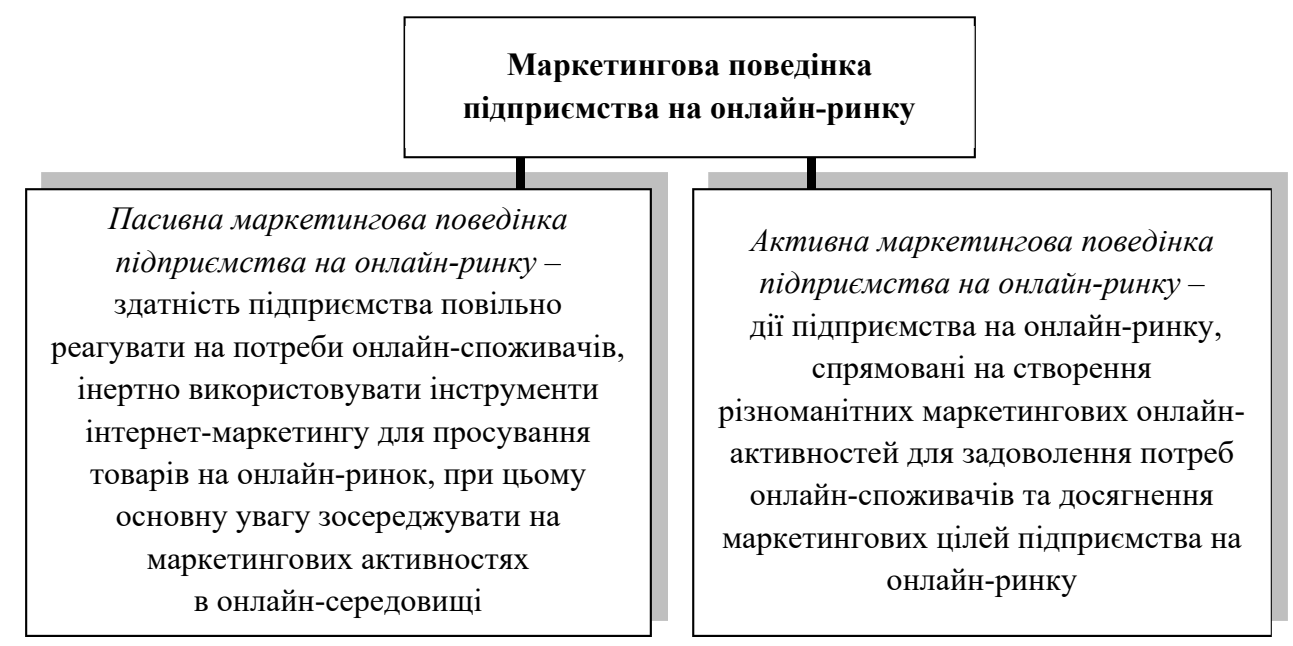

Рис. 4. Типи маркетингової поведінки підприємств на онлайн-ринку

Джерело: розроблено авторами

Задля досягнення активної поведінки підприємства на онлайн-ринку використовують ефективні інструменти інтернет-маркетингу для В2С- та В2В-ринків. Контент-маркетинг - це стратегія, що допомагає підприємствам генерувати ліди, збільшувати свою цільову аудиторію, підвищувати залучення, залучати потенційних клієнтів, 
підвищувати впізнавання бренду, збільшувати продажі та підвищувати лояльність клієнтів. Різні формати контенту допомагають ефективно досягти цих цілей. Можна також вести блог як для залучення трафіку на свій сайт, так і в освітніх цілях $[1 ; 3 ; 10]$.

Пошукова оптимізація означає, що потрібно оптимізувати сторінки сайту підприємства для досягнення високої позиції на сторінці результатів пошукової видачі. SEO - це набір методів, які дають змогу користувачам знаходити відповідний контент в Інтернеті. Це довгострокова стратегія, яка передбачає роботу з пошуковими запитами користувачів, швидкістю завантаження сторінок і побудовою посилальної маси на сайт $[6 ; 7 ; 14 ; 15]$.

Платна реклама - це стратегія, схожа на SEO, але різниця полягає в тому, що вона $\epsilon$ платною. Це контекстна реклама, реклама у Facebook та Instagram, таргетинг рекламної кампанії. Всі ці онлайн-активності допомагають залучати на сайт користувачів, які вже зацікавлені товаром $[11 ; 14 ; 15]$.

Email-розсилка - це добре продумана стратегія еmail-маркетингу, що дає змогу підвищувати впізнавання бренду й збільшувати продажі. Можна зіставляти рекламні кампанії з транзакційними листами, щоби підвищити ефективність цієї стратегії. За допомогою Automation 360 можна автоматично відправляти листи у відповідь на дії користувачів [6;7].

Соціальні мережі - це дуже потужні канали взаємодії з онлайн-споживачами. Люди все більше часу проводять в Інтернеті, а саме в соціальних мережах. Онлайн-користувачі займаються пошуками відгуків про підприємство чи товари у Facebook, шукають більш закулісну інформацію про бренди в Instagram. Крім того, вони, як правило, діляться вподобаним контентом зі своїми друзями. Використовуючи налаштування соціальних мереж, можемо збільшити продажі та залучення користувачів, підвищити комунікаційну взаємодію з цільовими сегментами $[2 ; 5 ; 7]$.

Маркетинг впливу (інфлюенсер-маркетинг) - це передача інформації про товари онлайн-покупцям через відомих блогерів в онлайн-середовищі. Вони допомагають просувати бренд на онлайн-ринку серед своєї аудиторії на взаємовигідних умовах [1].

Якщо переглянути конкретні маркетингові інструменти В2B, не важко помітити, що вони різняться індивідуальним підходом до клієнта та орієнтовані на збільшення ділових контактів у довгостроковій перспективі. Однак такі інструменти, як зв'язки 3 громадськістю та просування в Інтернеті, спрямовані більше не на привернення уваги тільки потенційних клієнтів, а на покращення репутації компанії та підвищення поінформованості про бренд загалом. Зауважимо, що особисті продажі та міжнародні виставки $є$ важливими інструментами для збільшення обсягу продажів підприємств, але за ефективної реалізації маркетингової онлайн-стратегії можна теж досягти значних результатів.

Висновки. Дослідження показують, що електронна комерція для секторів В2В та В2С продовжує активно зростати й прогресувати. В результаті цього сектори мають зробити процес покупки своїх товарів в Інтернеті максимально легким, зручним і зрозумілим. Це допоможе значно швидше досягнути мети та стати лідерами на ринку.

Внаслідок порівняльної характеристики підприємницької діяльності в секторах B2B та В2С визначено, що метою В2С є продаж товару або послуги швидко, поки споживач не пішов шукати її назад в пошуковик або на сайт конкурентів, а також підвищення лояльності кінцевого споживача. Метою В2В є демонстрація потенційному бізнес-клієнту особливостей роботи, переваг і репутації бізнесу на ринку.

Внаслідок розроблених моделей маркетингової поведінки підприємств на онлайнринку визначено особливості їх створення та запропоновано типи маркетингової поведінки підприємства на онлайн-ринку, такі як пасивна та активна, уточнено зміст понять. Задля досягнення активної поведінки підприємства на онлайн-ринку варто 
використовувати ефективні інструменти інтернет-маркетингу для В2С- та В2В-ринків, такі як контент-маркетинг, пошукова оптимізація, платна онлайн-реклама, email-poзсилка, соціальні мережі з можливістю рекламування й таргетингу, маркетинг впливу.

Подальшою перспективою дослідження може бути розгляд та вибір критеріїв, на основі яких можна розробити методику визначення маркетингової поведінки підприємства на онлайн-ринку.

\section{Список використаних джерел:}

1. Ancillai C., Terho H., Cardinali S., Pascucci F. Advancing social media driven sales research: Establishing conceptual foundations for B-to-B social selling. Industrial Marketing Management. 2019. Vol. 82. P. 293-308. DOI: https://doi.org/10.1016/j.indmarman.2019.01.002.

2. Appel G., Grewal L., Hadi R., Stephen A.T. The future of social media in marketing. Journal of the Academy of Marketing Science. 2020. № 48 (1). P. 79-95. DOI: https://doi.org/10.1007/ s11747-019-00695-1.

3. Park M., Lennon Sh. Brand name and promotion in online shopping contexts. Journal of Fashion Marketing and Management. 2009. № 13 (2). P. 149-160.

4. Sam K.M., Chatwin C.R. The mapping between business e-marketing mix and internet consumers' decision-making styles in e-commerce. Proceedings of the Fifth International Conference on Electronic Business. 2005. P. 411-418.

5. Felix R., Rauschnabel P.A., Hinsch C. Elements of strategic social media marketing. Journal of Business Research. 2017. № 70 (1). P. 118-126.

6. Drive business growth with a winning digital marketing strategy. URL: https://bit.ly/2VZLo73 (дата звернення: 10.11.2020).

7. Гвоздецкая И., Игнатьева И. Маркетинговые инструменты продвижения продукции на рынке b2b. URL: https://bit.ly/2K6witL (дата звернення: 01.12.2020).

8. Глобальное развитие e-Commerce. URL: https://bit.ly/2W45iyl (дата звернення: 10.12.2020).

9. Голубков Є. Маркетингові дослідження: теорія, практика і методологія. Москва : Фінпрес, 2005. $89 \mathrm{c}$.

10. Дік В., Лужецький М., Родіонов А. Електронна комерція. Москва : Московська фінансово-промислова академія, 2005. 122 с.

11. Заруднева А., Радченко Е. Особенности брендинга на В2В-рынке. 2010. 133 с.

12. Карачина Н. Економічна поведінка машинобудівних підприємств: теорія, методологія, практика управління : монографія. Вінниця, 2010. $416 \mathrm{c}$.

13. Козлова І. Визначення сутності поняття «економічна поведінка суб'єктів господарювання». Сучасні проблеми управління підприємством: теорія та практика : матеріали Міжнародної науково-практичної конференції. Харків, 2016. 54 с.

14. Кущ С., Смирнова М. Маркетинг на b2b рынках: отношенческий подход. Санкт-Петербург, 2010. $272 \mathrm{c.}$

15. Особливості інтернет-реклами на ринку b2b. URL: https://bit.ly/3osTD7Y (дата звернення: 15.11.2020).

16. Цапенко В. Економічна поведінка підприємств як основа для прийняття управлінських рішень. Бізнес-форум. 2014. № 11. С. 313-317.

\section{References:}

1. Ancillai C., Terho H., Cardinali S., Pascucci F. (2019) Advancing social media driven sales research: Establishing conceptual foundations for B-to-B social selling. Industrial Marketing Management, vol. 82, pp. 293-308. DOI: https://doi.org/10.1016/j.indmarman.2019.01.002.

2. Appel G., Grewal L., Hadi R., Stephen A.T. (2020) The future of social media in marketing. Journal of the Academy of Marketing Science, no. 48 (1), pp. 79-95. DOI: https://doi.org/10.1007/ s11747-019-00695-1.

3. Park M., Lennon Sh. (2009) Brand name and promotion in online shopping contexts. Journal of Fashion Marketing and Management, no. 13 (2), pp. 149-160.

4. Sam K.M., Chatwin C.R. (2005) The mapping between business e-marketing mix and internet consumers' decision-making styles in e-commerce. In Proceedings of the Fifth International Conference on Electronic Business, pp. 411-418. 
5. Felix R., Rauschnabel P.A., Hinsch C. (2017) Elements of strategic social media marketing. Journal of Business Research, no. 70 (1), pp. 118-126.

6. Drive business growth with a winning digital marketing strategy. Available at: https://bit.ly/2VZLo73 (accessed 10 November 2020).

7. Gvozdetskaya I., Ignatieva I. Marketinhovye instrumenty prodvizhenia produktsii na rynke b2b [Marketing tools for product promotion in the b2b market]. Available at: https://bit.ly/2K6witL (accessed 01 December 2020).

8. Hlobalnoe razvitie e-Commerce. [Global development of e-Commerce]. Available at: https://bit.ly/2W45iy1 (accessed 10 December 2020).

9. Golubkov E. (2005) Marketynhovi doslidzhennia: teoriia, praktyka i metodolohiia [Marketing research: theory, practice and methodology]. Moscow: Finpress. P. 89.

10. Dick V., Luzhetsky M., Rodionov A. (2005) Elektronna komertsiia [E-commerce]. Moscow: Moscow Financial and Industrial Academy. P. 122.

11. Zarudneva A., Radchenko E. (2010) Osobennosti brendinha na B2B-rynke [Features of branding in the B2B market]. P. 133.

12. Karachina N. (2010) Ekonomichna povedinka mashynobudivnykh pidpryiemstv: teoriia, metodolohiia, praktyka upravlinnia [Economic behavior of machine-building enterprises: theory, methodology, management practice]. Vinnytsia. P. 416.

13. Kozlova I. (2016) Vyznachennia sutnosti poniattia "ekonomichna povedinka" subiektiv hospodariuvannia. Suchasni problemy upravlinnia pidpryiemstvom: teoriia ta praktyka. Mizhnarodna naukovo-praktychna konferentsiia [Defining the essence of the concept of "economic behavior" of economic entities. Modern problems of enterprise management: theory and practice. International scientific-practical conference]. Kharkiv. P. 54.

14. Kushch S., Smirnova M. (2010) Marketinh na b2b rynkakh: otnoshencheskii podkhod [Marketing in b2b markets: a relational approach]. SPb. P. 272.

15. Osoblyvosti internet-reklamy na rynku b2b. Available at: https://bit.ly/3osTD7Y (accessed 15 November 2020).

16. Tsapenko V. (2014) Ekonomichna povedinka pidpryiemstv yak osnova dlia pryiniattia upravlinskykh rishen [Economic behavior of enterprises as a basis for management decisions]. Biznes-forum [Business-forum], vol. 11, pp. 313-317. 